\title{
1. Introduction: dialogues between international and national laws relating to intangible cultural heritage Marie Cornu and Anita Vaivade
}

\section{BEYOND ‘INTANGIBLE CULTURAL HERITAGE’ LAW}

This collective research focuses on intangible cultural heritage and the way it is more or less explicitly legally apprehended at an international level as well as in different national legal regimes. In this regard, the UNESCO Convention for the Safeguarding of the Intangible Cultural Heritage adopted in 2003 (hereafter the 2003 Convention) has sparked an unprecedented legal debate that goes far beyond the purely technical issue of integrating an international body of law into national legislations. Several trends emerge from the different points of contact between international and national laws that deserve to be carefully studied.

First of all, we must ask how national laws - some of which have been developing protection tools, in a somewhat scattered fashion over the past decades, on elements such as folklore, language or other traditional know-hows - reorganise themselves in the wake of this new category of intangible cultural heritage. The novelty of this notion has been highlighted with regard to the elements it targets (intangible elements, in contrast to the tangible elements usually protected by cultural heritage law), but it also reveals the revolutionary heritagisation process that it implies. This process implicates the individuals - the holders of this heritage - in claiming a sense of belonging. Article 2 of the 2003 Convention defines intangible cultural heritage as manifesting through a set of practices, representations, expressions, knowledge, etc. that individuals or groups 'recognise as part of their cultural heritage'. There is in this process a type of an attribution claim, a ground-breaking perspective in cultural heritage law, classically defined by what has been called an 'object-oriented' approach to protection, centred around the notion of outstanding value. Intangible cultural heritage is thus located on a radically different plane because it principally derives from a dynamic of recognition. 
This process obviously entails an intimate, foundational connection that, in a certain way, reflects a sense of belonging, which is very clearly put forward in the 2003 Convention. ${ }^{1}$ In what way would this new approach to the notion of cultural heritage have a reshaping power? We have identified this feature as a potential dynamic of legal globalisation.

Secondly, the legal conceptualisation mechanisms of the notion of intangible cultural heritage reveal interlacing phenomena of different rights from various sources and scopes: classically state rights, but also rights implemented by local authorities (and community laws), rights of individuals and groups, individual and collective rights, the right to protect cultural heritage and the right to cultural heritage. This densification of the coexisting rights and interests applied to intangible cultural heritage forces a reconsideration of the checks and balances that usually underpin the legal protection of cultural heritage. Our research hypothesis is that intangible cultural heritage, a new category at least in the legal language, is an interesting vantage point to apprehend deep movements of the law, it being understood that intangible cultural heritage law has certainly not reached its maturity point. It is a branch of the law in development, which tries to set its mark in the general field of cultural heritage law. This is why this examination of states' understanding of intangible cultural heritage is interesting, both at the level of legislations and the juridicisation of the relevant rights.

With this in mind, the research tries to convey the richness and the diversity of the national experiences. The first step was to understand how the states positioned themselves in relation to the 2003 Convention, how they appropriated this issue of intangible cultural heritage with regard to their public policies, but, more specifically, in respect of their legal tools already in place. The goal was to highlight converging phenomena, reciprocal influences, borrowing dynamics, of imitation or singularisation from a vertical standpoint, between national laws and international law, and a horizontal standpoint between national laws. We analyse these dialogues arranged across various registers.

We obviously had to study the implementation modalities of the 2003 Convention. The example of the inventory is interesting to understand the role of the state in the heritagisation process and how it is defined in relation to the one recognised by heritage holders. Article 12 of the 2003 Convention states that ' $[\mathrm{t}] \mathrm{o}$ ensure identification with a view to safeguarding, each State Party

1 With regard to the debate surrounding the sense of belonging and its legal translation see: Marie Cornu, 'A qui appartient le patrimoine culturel immatériel?' in Julia Csergo, Christian Hottin and Pierre Schmit (eds), Le patrimoine culturel immatériel au seuil des sciences sociales: Actes du colloque de Cerisy-la-Salle, September 2012 (Éditions de la Maison des sciences de l'homme 2020, DOI: 10.4000/books. editionsmsh.15990). 
shall draw up, in a manner geared to its own situation, one or more inventories of the intangible cultural heritage present in its territory [...]'. It is one of the few obligations of the states, in addition to the one to 'take the necessary measures to ensure the safeguarding of the intangible cultural heritage present in [its] territory' (article 11) and the obligation to periodically submit a report to the Intergovernmental Committee for the Safeguarding of the Intangible Cultural Heritage on the legislative, regulatory and other measures taken for the implementation of the 2003 Convention (article 29). The provision 'to take the necessary measures' implies, if not a true structured policy pertaining to intangible cultural heritage - whether or not based on legislation - at least actions aiming at ensuring the safeguarding of this newly recognised type of heritage.

Regarding the inventories, a number of conditions are required by the 2003 Convention, notably the fact that the identification of an element predicates the participation of the relevant community, or groups or individuals. But neither the notion of community nor that of participation are conceived here as legal notions, even though the interpretative texts, for example, the Operational Directives for the Implementation of the 2003 Convention, as well as the Ethical Principles for Safeguarding Intangible Cultural Heritage, underline their importance. The states translated in different legal ways their obligation to draw up an inventory. The ways the states identify for these inventories, through the criteria and normativity they create, the elements that they consider as representative of the intangible cultural heritage of humanity, reveal their conception of this newly recognised type of cultural heritage. Their understanding sometimes diverges from the international approach. The 2003 Convention leaves considerable leeway to states in choosing the approach they consider best suited to its implementation, notably to ensure the safeguarding of intangible cultural heritage present in their territories, which again illustrates the interest to observe how national legislations are developed. ${ }^{2}$

Nevertheless, in this perspective of a dialogue between international and national laws, we have not limited our scope solely to the question of the implementation of the 2003 Convention by the states. We also sought to approach this question through a more open perspective by observing the numerous ways in which the fabric of intangible cultural heritage finds a legal expression, even beyond any references to the 2003 Convention.

2 On the diversity of scientific methodologies and the legal forms for the implementation of article 12 of the 2003 Convention see: Marie Cornu and Rieks Smeets, 'Article 12: Inventories' in Janet Blake and Lucas Lixinski (eds), The 2003 UNESCO Intangible Heritage Convention: A Commentary (OUP 2020). 
We were thus able to observe how many legislations develop tools, without always explicitly linking them to or naming them as intangible cultural heritage law but with similar aims, to safeguard practices, know-how, knowledge, that we could very well assimilate to elements of 'intangible cultural heritage'. According to this approach, we can identify an intangible cultural heritage law that finds different legal spheres of expressions, for example, in fine-craft labels, the protection of fundamental rights, cultural rights, or linguistic rights, and sometimes intellectual property law, which has very close links to intangible cultural heritage. The promotion of some activities or productions that could be defined as elements of intangible cultural heritage according to the 2003 Convention, is thus being channelled differently, and it seemed appropriate to include these more invisible legal norms in our research.

Our stance of going beyond studying an explicit 'intangible cultural heritage law', or a law that refers to 'intangible cultural heritage' as a category for public action and that relies on legal grounds, was not taken without raising a number of issues concerning methodology. We were of course interested in an intangible cultural heritage law that 'expresses a public policy specific to intangible cultural heritage', ${ }^{3}$ meaning intangible cultural heritage considered in a nominal way. If a number of states are starting to legislate on intangible cultural heritage law, to incorporate this notion in the law, to legally name it, it continues to be the case nevertheless that 'the number of national legal provisions expressly meant to apply to "intangible cultural heritage" remains very limited'. ${ }^{4}$ Hence our choice to approach the issue more broadly and openly: may some rules be related to an intangible cultural heritage law, inasmuch as they express a type of public policy specific to this heritage, without however naming it? This stance postulates that there are some elements that can be qualified as 'intangible cultural heritage' without being named as such. But then, how to perform this exercise of ordering such seemingly miscellaneous material; how to infer the characteristics of this law, which could lead us to admit that, fundamentally, this or that disposition belongs to an intangible cultural heritage law? For instance, we considered that part of this body of law are all the rules explicitly applicable to 'folklore'/'know-hows'/'traditional specialty', and more generally to the activities that resort to tradition (for example the provisions authorising practices involving animals which are derived from a long tradition, such as corridas and bull races or cockfights). ${ }^{5}$ This type of

3 Noé Wagener, 'Problèmes de méthode d'une étude de droit comparé sur le patrimoine culturel immatériel (compte-rendu)' (2016) Online Research Notebook 'Droit, Patrimoine \& Culture: Nouveaux Champs de Recherche'<https://dpc.hypotheses.org/ 634> accessed 5 February 2020.

ibid.

See Part IV of this volume. 
approach entailing an ordering of the field, which should reflect an image of what should be seen as intangible cultural heritage, can be criticised. This is notably because this approach would imply codifying and reordering the rules surrounding a concept whose scope and properties would have been previously settled, and thus also implies an essentialising approach to intangible cultural heritage.

But intangible cultural heritage as a legal concept does not refer to things that should be defined with regard to intrinsic criteria of cultural value, such as with tangible cultural heritage recognition based on the historical or artistic value of some objects. We must go back to the definition suggested by the 2003 Convention in its article 2 -

\footnotetext{
The 'intangible cultural heritage' means the practices, representations, expressions, knowledge, skills - as well as the instruments, objects, artefacts and cultural spaces associated therewith - that communities, groups and, in some cases, individuals recognize as part of their cultural heritage. This intangible cultural heritage, transmitted from generation to generation, is constantly recreated by communities and groups in response to their environment, their interaction with nature and their history, and provides them with a sense of identity and continuity, thus promoting respect for cultural diversity and human creativity $[\ldots]$.
}

If intangible cultural heritage refers to immaterial elements, cultural or social practices, know-how, knowledge in various forms of expressions, etc., these human activities are not, in themselves, recognised as intangible cultural heritage. More specifically, we could say that the only criteria to determine a heritage value is the reference to tradition - the idea that the recognition of a value derives from its relation to a specific temporality, 'transmitted from generation to generation'. But, on the one hand, nothing is really specified with regard to this relation to time - the elements inscribed on the Representative List of the Intangible Cultural Heritage of Humanity or the List of Intangible Cultural Heritage in Need of Urgent Safeguarding are not always ancient. On the other hand, the key criterion does not reside in this aspect but in the heritagisation process itself. This is what singles out this heritage in the broader field of cultural heritage, and that is evidenced by the additional list of domains in the 2003 Convention to illustrate the notion:

The 'intangible cultural heritage', as defined in paragraph 1 above, is manifested inter alia in the following domains: (a) oral traditions and expressions, including language as a vehicle of the intangible cultural heritage; (b) performing arts; (c) social practices, rituals and festive events; (d) knowledge and practices concerning nature and the universe; (e) traditional craftsmanship.

This text does not provide a list of intangible cultural heritage elements but only indicates that intangible cultural heritage can be observed through these 
modes of expression and practices. The defining criterion is thus a claimed sense of belonging.

We then asked ourselves whether the 'object' could exist without the 'word' as long as the heritagisation process could be identified, and as long as this claiming process existed. We were able to identify family ties with other legal actions; hence the interest we had for some mechanisms of creation and attribution of labels, neighbouring 'legal objects' in relation to which the category of 'intangible cultural heritage' is not necessarily used. This approach presented an opportunity to observe how intangible cultural heritage 'has since been disseminated - in extremely interesting ways and forms to study, and [in particular] - in national laws '. ${ }^{6}$ We can come back here to the example of language, which in several states is qualified as heritage, sometimes as a common heritage of the nation, but which remains outside of the elements recognised as part of intangible cultural heritage at the international level.

Yet, the exercise goes even deeper. We were also interested in what national actors make of intangible cultural heritage, notably what previous notions they recycle, and not only under the banner of intangible cultural heritage. Thus, we applied both a synchronic approach to this research, studying what intangible cultural heritage is today, and diachronic, by studying historical figures, some of which are part of the genealogy of the 2003 Convention, such as the notion of folklore or expressions of folklore. ${ }^{7}$ To understand the relationships between national laws and the 2003 Convention, we had to reinstate the notion of 'intangible cultural heritage' in an extended historical trajectory, in order to observe its various strata. The rules pertaining to intangible cultural heritage are, in a general way, scattered across many legal instruments, organised according to their themes, content and normative density. They sometimes materialise into legal regimes but can also be derived from soft law mechanisms. Several states have drafted laws on intangible cultural heritage, or cultural heritage laws are amended to include the notion of intangible cultural heritage. ${ }^{8}$ National intangible cultural heritage law, in some instances, distances itself from the 2003 Convention by developing its own mechanisms.

\footnotetext{
6 Wagener (n 3). On the reflection about our methodology, see also Anita Vaivade and Noé Wagener, 'National Laws Related to Intangible Cultural Heritage: Determining the Object of a Comparative Study' (2017) 2 The Santander Art and Culture Law Review 92.

7 See ch 2 'Linking new intangible cultural heritage law with a legal past' and ch 7 'The interactions between intangible cultural heritage and intellectual property law'.

8 On a diversity of examples of such approaches, see Anita Vaivade, 'Article 13: Other Measures for Safeguarding: Developing Intangible Cultural Heritage Policies and Legislation at the National Level' in Blake and Lixinski (n 2), and ch 9 'Translating the 2003 Convention into national laws'.
} 


\section{CORRELATING A VARIETY OF EXPERIENCES}

Collecting data from several states characterised by diverse legal traditions and from different regions of the world, this research offers a panorama of examples derived from 26 states, amongst which 24 are parties to the 2003 Convention: Algeria, Belgium, Brazil, China, Congo, Egypt, Estonia, France, Germany, Iceland, Iran, Italy, Kenya, Latvia, Madagascar, Malawi, Mali, Mexico, Morocco, Poland, Spain, Switzerland, Zambia and Zimbabwe. In addition, the choice was made to incorporate within the scope of the research two non-party states to the Convention (the United States and Canada) in order to enrich the comparison.

Our goal was obviously not to undertake a systematic comparative study. Such an enterprise would have been unrealistic with regard to the number of countries surveyed and the unequal level of the answers to the questionnaire (see hereunder on the methodology), and also the diffused nature of the body of elements studied. We indeed have met some difficulty in inferring comparative observations considering the limited knowledge on the extra-legal contexts, notably social, historical, political and others that influence the law and its evolutions. The idea was instead to gather a sufficient amount of data to trigger a reflection on the various legal registers mobilised in relation to intangible cultural heritage and on the overarching questions that we think should be more specifically studied. All the above does not, of course, exclude some correlations; but we preferred to underline and question the diversity of approaches, although leaving space to identify converging phenomena.

The correlative study of these 26 national experiences, which is the particularity of the present monograph, is organised around four research axes:

1. The first axis explores how each state has defined the category of 'intangible cultural heritage', and how the dialogue was established between the 2003 Convention, their respective legal system and their past experiences.

2. The second axis focuses on interactions between intangible cultural heritage law and three other branches of the law that were particularly identified as complex: human rights, environmental law and intellectual property law.

3. The third axis aims at analysing different processes of formulating, in legal terms and at the national level, safeguarding measures of intangible cultural heritage.

4. The fourth axis offers a reflection on legal claims brought in relation to intangible cultural heritage issues from the study of case law. 


\section{A FEW WORDS ABOUT THE PROCEEDINGS OF THE PROJECT}

The study was launched in 2014 just before the tenth anniversary of the entry into force of the 2003 Convention. ${ }^{9}$ Thus, the opportunity arose to analyse how this international instrument influenced the laws of several state parties and non-parties in its early years. The first biennium of the Osmose ${ }^{10}$ programme (2014-2015) was devoted to setting a common framework to undertake the comparative study, developing a network of legal scholars interested in the field and identifying research direction. The second biennium (2016-2017) was used to set a shared comparative method and to decide the main axes of research. A qualitative questionnaire was drafted and addressed to identified respondents at the end of the year 2016. The answers gathered have often been complemented and commented on by staff members of governmental institutions in charge of intangible cultural heritage, anthropologists and ethnologists from the various states.

During the development phase of the research, several thematic meetings open to the public were organised to deepen the study of certain aspects of intangible cultural heritage law, including with the participation of some respondents contributing to the project. These meetings were notably on the development of the concept of intangible cultural heritage (Paris, 4 November 2014), on subjective rights related to intangible cultural heritage safeguarding (Riga, 29 June 2015), on the intangible cultural heritage in nature - associated spaces, resources and practices (Riga, 8 September 2017), as well as on labels and other legal mechanisms of intangible cultural heritage (Paris, 10 November 2017). It is on the basis of these documents and exchanges that the final report of the research was undertaken.

The realisation of the study is presented in the online research notebook of the Osmose project, ${ }^{11}$ which continues to exist as an archive of the various activities. The project was also an opportunity to develop and publish an annotated bibliography of the literature highlighting the legal issues surrounding

9 Initial international collaboration regarding the field of intangible cultural heritage law resulted in the proceedings of a conference that took place in Paris. See: Cornu Marie, Jérôme Fromageau and Christian Hottin (eds), Droit et patrimoine culturel immatériel (1'Harmattan 2013).

10 The name for this project came from the French-Latvian intergovernmental programme 'Osmose' for bilateral scientific cooperation. This programme provided the initial funding to undertake this research.

11 Online Research Notebook 'Droit, Patrimoine \& Culture : Nouveaux Champs de Recherche'<https://dpc.hypotheses.org/le-projet-osmose> accessed 5 February 2020. 
the safeguarding of intangible cultural heritage. ${ }^{12}$ A summary report of the Osmose project ${ }^{13}$ was also published and presented during the seventh General Assembly of the States Parties to the 2003 Convention in Paris in June 2018, as a side event. ${ }^{14}$ This event was possible thanks to the collaboration of the Living Heritage Section of the UNESCO Secretariat and the Permanent Delegations of France and Latvia to UNESCO. The manuscript of the present monograph also benefited from a focused reflection during a concluding event in Paris, organised at the Institute for Advanced Study on 14 February 2019. ${ }^{15}$

The ambition of this research, for that matter reflected in the title of the present monograph, was to highlight the dynamic interplay between various legal strata (international, national, regional and local) relating to the safeguarding of intangible cultural heritage, as well as the dialogues between various institutions whose actions also relate to intangible cultural heritage. This work trajectory enabled a meaningful dialogue between lawyers and anthropologists, ethnologists and folklorists. Researchers from various disciplines were invited to give their opinion on the research and the way the legal analysis could resonate with their own work. Intangible cultural heritage brings together this diversity of disciplines and there is an obvious profit in confrontng these different approaches, in particular their relation to this new type of normativity and the way it radically modifies the heritagisation process, and considerably influences the relationship between the actors, the experts, the scholars, the decision-makers and the project holders. The Osmose project is being followed up in another biennium 2020-2021. For this biennium, we chose to address more systematically the different types of normativity and the way researchers, throughout their theory and practice, and by naming and

12 Lily Martinet, 'Bibliographie' (2018) < https://dpc.hypotheses.org/files/2018/06/ Biblio-LM_080118_amend_AV.pdf> accessed 5 February 2020.

13 'Intangible Cultural Heritage in National Laws: A Dialogue with the 2003 Convention. Summary Overview of the "Osmose" Research Report" $(2018)<\mathrm{http}: / \mathrm{dpc}$ .hypotheses.org/files/2018/06/Osmose_rapport_synthese_2018_EN_5juin2018_10h .pdf $>$ accessed 5 February 2020.

14 'Intangible Cultural Heritage in National Laws - Presentation of the International Comparative Research "Osmose"' (General Assembly of States Parties to the UNESCO Convention for the Safeguarding of the Intangible Cultural Heritage, Paris, 6 June 2018) <https://ich.unesco.org/en/6-june-1345-intangible-cultural-heritage-in-national -laws-01003> accessed 5 February 2020.

15 'Le patrimoine culturel immatériel dans les droits nationaux - dialogue avec la convention de l'UNESCO de 2003' (Institut d'études avancées, Paris, 14 February 2019) <https://www.paris-iea.fr/fr/evenements/le-patrimoine-culturel-immateriel-dans -les-droits-nationaux-dialogue-avec-la-convention-de-l-unesco-de-2003> accessed 5 February 2020. 
developing key concepts (those of community, heritage bearers and participation), contribute to regulating this field of intangible cultural heritage.

\section{THE OSMOSE SCIENTIFIC TEAM}

This French-Latvian project was led by Marie Cornu (Institut des sciences sociales du Politique, École Normale Supérieure Paris-Saclay, Université Paris Nanterre - Centre national de la recherche scientifique) and Anita Vaivade (UNESCO Chair on Intangible Cultural Heritage Policy and Law - Latvian Academy of Culture). Lily Martinet (Senior Research Fellow, Max Planck Institute Luxembourg for Procedural Law) became the coordinator for the comparative study in 2017 , a crucial year in the organisation of the international collaboration and development of the methodological and comparative tools. Over the whole period of its implementation, the project was a collaborative work within a broader French-Latvian team of researchers - Jérôme Fromageau, Clea Hance, Vincent Négri, Noé Wagener, Catherine Wallaert and Liga Âbele. The project also benefited from the contributions of Christian Hottin, Emilie Terrier, Marie Trape, Dace Bula, Sanita Pretkalniņa and Daina Teters. The manuscript presenting research results was drafted in French, and Clea Hance and Lily Martinet played a substantial role in the development of the present publication and undertook its translation into English.

During the initial collaboration phase and during the realisation of the project, several members of the team defended their PhDs on themes relating to the project. The doctoral theses of Anita Vaivade, 'The Conceptualization of Intangible Cultural Heritage in Law'16 and Noé Wagener 'State Services for the Protection of Cultural Heritage', respectively defended in 2011 and 2014, enriched the development of this collaborative research. Two other doctoral theses were defended on topics relating to the Osmose project: Lily Martinet's thesis entitled 'Traditional Cultural Expressions in International Law', defended in 2017, ${ }^{17}$ and Emilie Terrier's entitled 'Towards a New Copyright Figure: the Assertion of a Cultural Public Logic', defended in 2018. At the time of writing this monograph, and further expanding on this topic, several $\mathrm{PhDs}$ are underway - in France, Clea Hance's thesis entitled 'The Participation of Heritage Holders: A Legal Standard?' and Anthony Saillard's entitled 'The Input of European Law in the Construction of the Cultural Heritage Laws', and in Latvia, Lìga Ābele's thesis entitled 'The Assessment of Intangible

16 Anita Vaivade, Nemateriālais kultūras mantojums starptautiskajās un Latvijas tiesībās (LU LFMI 2016).

17 Lily Martinet, Les expressions culturelles traditionnelles en droit international (IRJS 2019). 
Cultural Heritage Holders as a Political Instrument', and Digne Ūdre's entitled 'Ideologies Interpreted in a Visual Way: Mythological Ornamentation as Contested Cultural Heritage in Contemporary Latvia'. Thus, this project continues to have a formative function contributing to fruitful parallel research.

This project was supported by a Scientific Committee: Associate Professor Janet Blake (University of Shahid Beheshti (Tehran)); Isabelle Chave (Chief Curator at the French Ministry of Culture, Heritage Directorate, Department of Research Steering and Scientific Policy); Tim Curtis (Secretary of the 2003 Convention); Professor Manlio Frigo (University of Milan); and Professor Kamal Puri (Queensland University of Technology). The fulfilment of this research was made possible thanks to the generous contribution of the respondents (listed hereunder) necessary to collect the primary data. 


\section{ANNEX: TABLE OF THE RESPONDENTS WHO CONTRIBUTED TO THE OSMOSE PROJECT ${ }^{1}$}

\begin{tabular}{|c|c|c|}
\hline States & Name & Title and Institution \\
\hline \multicolumn{3}{|c|}{ States Parties } \\
\hline \multicolumn{3}{|l|}{ Group I } \\
\hline Germany & $\begin{array}{l}\text { Sophie } \\
\text { Schönberger }\end{array}$ & Professor of Public Law, Heinrich Heine University Düsseldorf \\
\hline \multirow[t]{2}{*}{ Belgium } & $\begin{array}{l}\text { Marie-Sophie de } \\
\text { Clippele }\end{array}$ & Postdoctoral Researcher FRS-FNRS, Université Saint-Louis Bruxelles \\
\hline & Marc Jacobs & $\begin{array}{l}\text { Professor of Heritage Studies, Faculty of Design Sciences, University } \\
\text { of Antwerp and UNESCO Chair on Critical Heritage Studies and } \\
\text { the Safeguarding of Intangible Cultural Heritage, Vrije Universiteit } \\
\text { Brussel }\end{array}$ \\
\hline \multirow[t]{2}{*}{ Spain } & $\begin{array}{l}\text { Sara González } \\
\text { Cambeiro }\end{array}$ & Anthropologist, Labrit Patrimonio \\
\hline & $\begin{array}{l}\text { Cristina } \\
\text { Sánchez-Carretero }\end{array}$ & $\begin{array}{l}\text { Researcher in Anthropology, Institute of Heritage Sciences (Incipit), } \\
\text { Spanish National Research Council (CSIC) }\end{array}$ \\
\hline \multirow[t]{4}{*}{ France } & Jérôme Fromageau & Dean of the Jean Monet Law Faculty, Paris-Sud University \\
\hline & Christian Hottin & $\begin{array}{l}\text { Director of Studies, Department of Conservators-Restorers, Institut } \\
\text { national du patrimoine }\end{array}$ \\
\hline & Lily Martinet & $\begin{array}{l}\text { Senior Research Fellow, Institute Max Planck Luxembourg for } \\
\text { Procedural Law }\end{array}$ \\
\hline & Noé Wagener & Professor of Public Law, University of Rouen Normandy \\
\hline Iceland & $\begin{array}{l}\text { Vilhelmína } \\
\text { Jónsdóttir }\end{array}$ & $\begin{array}{l}\text { Lawyer, Graduate Student in Ethnology and Folklore, University of } \\
\text { Iceland }\end{array}$ \\
\hline Italy & Sabrina Urbinati & $\begin{array}{l}\text { Associate Researcher, University of Milano-Bicocca, Qualified as } \\
\text { Associate Professor in Italy }\end{array}$ \\
\hline Switzerland & $\begin{array}{l}\text { Antoinette Maget } \\
\text { Dominicé }\end{array}$ & $\begin{array}{l}\text { Professor, Institut für Kunstgeschichte, Ludwig Maximilian University } \\
\text { of Munich }\end{array}$ \\
\hline \multicolumn{3}{|l|}{ Group II } \\
\hline \multirow[t]{3}{*}{ Estonia } & Ave Paulus & Doctoral Student, University of Tartu \\
\hline & Margit Siim & $\begin{array}{l}\text { Coordinator of Culture Programmes, Estonian National Commission } \\
\text { for UNESCO }\end{array}$ \\
\hline & Epp Tamm & Intangible Heritage Specialist, Estonian Folk Culture Centre \\
\hline
\end{tabular}

1 The list of respondants is given in alphabetical order, regardless of the extent of their contributions to the national questionaires. Affiliations and titles were updated in April 2020. 


\begin{tabular}{|c|c|c|}
\hline States & Name & Title and Institution \\
\hline \multirow[t]{3}{*}{ Latvia } & Līga Ābele & $\begin{array}{l}\text { Doctoral Student, UNESCO Chair on Intangible Cultural Heritage } \\
\text { Policy and Law, Latvian Academy of Culture }\end{array}$ \\
\hline & Dace Bula & Director, Institute of Literature, Folklore and Art, University of Latvia \\
\hline & Anita Vaivade & $\begin{array}{l}\text { Adjunct Professor, UNESCO Chair on Intangible Cultural Heritage } \\
\text { Policy and Law, Latvian Academy of Culture }\end{array}$ \\
\hline Poland & Hanna Schreiber & $\begin{array}{l}\text { Assistant Professor, Faculty of Political Science and International } \\
\text { Studies, University of Warsaw }\end{array}$ \\
\hline \multicolumn{3}{|l|}{ Group III } \\
\hline Brazil & Anita Mattes & $\begin{array}{l}\text { Fellow Visitor Researcher, University of Milano-Biccoca, PhD, } \\
\text { Université Paris-Saclay, Lawyer, Studio Mattes }\end{array}$ \\
\hline Mexico & $\begin{array}{l}\text { Martin Michaus } \\
\text { Esthefania de } \\
\text { Pando }\end{array}$ & $\begin{array}{l}\text { Lawyer, Basham, Ringe y Correa S.C. } \\
\text { Corporate Legal Counsel of RGIS }\end{array}$ \\
\hline \multicolumn{3}{|l|}{ Group IV } \\
\hline China & Wang Li & Associate Professor, Central South University Law School \\
\hline Iran & Susan Cheraghchi & $\begin{array}{l}\text { Legal Expert and Adviser, Iranian Cultural Heritage, Handicrafts and } \\
\text { Tourism Organization (ICHHTO); Researcher of the cultural heritage } \\
\text { law of Iran }\end{array}$ \\
\hline \multicolumn{3}{|l|}{ Group V(a) } \\
\hline Congo & $\begin{array}{l}\text { Ulrich Kévin } \\
\text { Kianguebeni }\end{array}$ & Lecturer, Law School, Marien Ngouabi University, Brazzaville \\
\hline Kenya & $\begin{array}{l}\text { Kiprop Lagat } \\
\text { George Litswa }\end{array}$ & $\begin{array}{l}\text { Director of Culture, Ministry of Sport, Culture and Arts } \\
\text { Cultural Officer, Culture and Heritage Museums }\end{array}$ \\
\hline Madagascar & $\begin{array}{l}\text { Anjavola } \\
\text { Razafinarivo } \\
\text { Tahina } \\
\text { Ratsiambakaina }\end{array}$ & $\begin{array}{l}\text { Head of the Department of Design and Innovation, Ministry of } \\
\text { Industry, Trade and Crafts } \\
\text { Head of Department, Ministry of Handicraft, Culture and Heritage }\end{array}$ \\
\hline Malawi & $\begin{array}{l}\text { Christopher } \\
\text { Magomelo }\end{array}$ & $\begin{array}{l}\text { Senior Assistant Executive Secretary, Malawi National Commission } \\
\text { for UNESCO }\end{array}$ \\
\hline Mali & Moulaye Coulibaly & National Director of Cultural Heritage \\
\hline Zambia & $\begin{array}{l}\text { Munukayumbwa } \\
\text { Munyima }\end{array}$ & $\begin{array}{l}\text { Research Fellow, Institute of Economic and Social Research, } \\
\text { University of Zambia }\end{array}$ \\
\hline $\begin{array}{l}\text { Zimbabwe } \\
\text { Group V(b) }\end{array}$ & Elvas Mari & Former Director, National Arts Council of Zimbabwe \\
\hline $\begin{array}{l}\text { Algeria } \\
\text { Egypt }\end{array}$ & Jihane Chedouki & $\begin{array}{l}\text { Postdoctoral Fellow, Forum Transregionale Studien Europe in the } \\
\text { Middle East - The Middle East in Europe }\end{array}$ \\
\hline
\end{tabular}




\begin{tabular}{lll}
\hline States & Name & Title and Institution \\
\hline Non-Party States & \\
Canada & Antoine Gauthier & Director General, Conseil québécois du patrimoine vivant (CQPV) \\
& Robert K Paterson & $\begin{array}{l}\text { Professor Emeritus, Peter A. Allard School of Law, University of } \\
\text { British Columbia }\end{array}$ \\
& & Doctoral Student, University Paris-Saclay, Fondation des Sciences du \\
USA & Clea Hance & Patrimoine \\
& & Folklife Specialist, American Folklife Center, Library of Congress \\
\hline
\end{tabular}

Note: Group I regional electoral groups of UNESCO. 